\title{
СОЛЯНАЯ ТЕКТОНИКА В ОКРАИННО-КОНТИНЕНТАЛЬНЫХ ЭВАПОРИТОВЫХ БАССЕЙНАХ АРКТИКИ
}

\section{Шипилов Э.В.}

Полярный геофизический институт, Мурманск, shipilov@pgi.ru

По результатам сейсмических исследований рассмотрены окраинно-континентальные эвапоритовые бассейны Арктического региона. Охарактеризованы комплексные геолого-геофизические признаки распознания и выделения соленосных структур - подушек и диапиров. Проиллюстрированы разрезами примеры проявления эвапоритового диапиризма в разновозрастных осадочных бассейнах запада Баренцевоморского шельфа, севера Карского шельфа, юго-запада моря Лаптевых в Хатангском заливе, Канадского Арктического архипелага. Сделаны выводы относительно факторов обусловивших тектоническую подвижность бассейнов окраин и спровоцировавших соляную тектонику.

В ряде палеозойско-мезозойских осадочных бассейнов континентальных окраин Арктики геолого-геофизическими работами установлены проявления галокинеза [1-3, 5, 8, 10-13]. Характерной особенностью этих прогибов является наличие в них диапироподобных структур, генезис которых однозначно определяется по комплексу геолого-геофизических признаков. На временных разрезах МОГТ эвапоритовые тела выделяются в первую очередь специфической геометрией, характером причленения к этому телу отражающих горизонтов осадочного чехла, хаотической внутренней
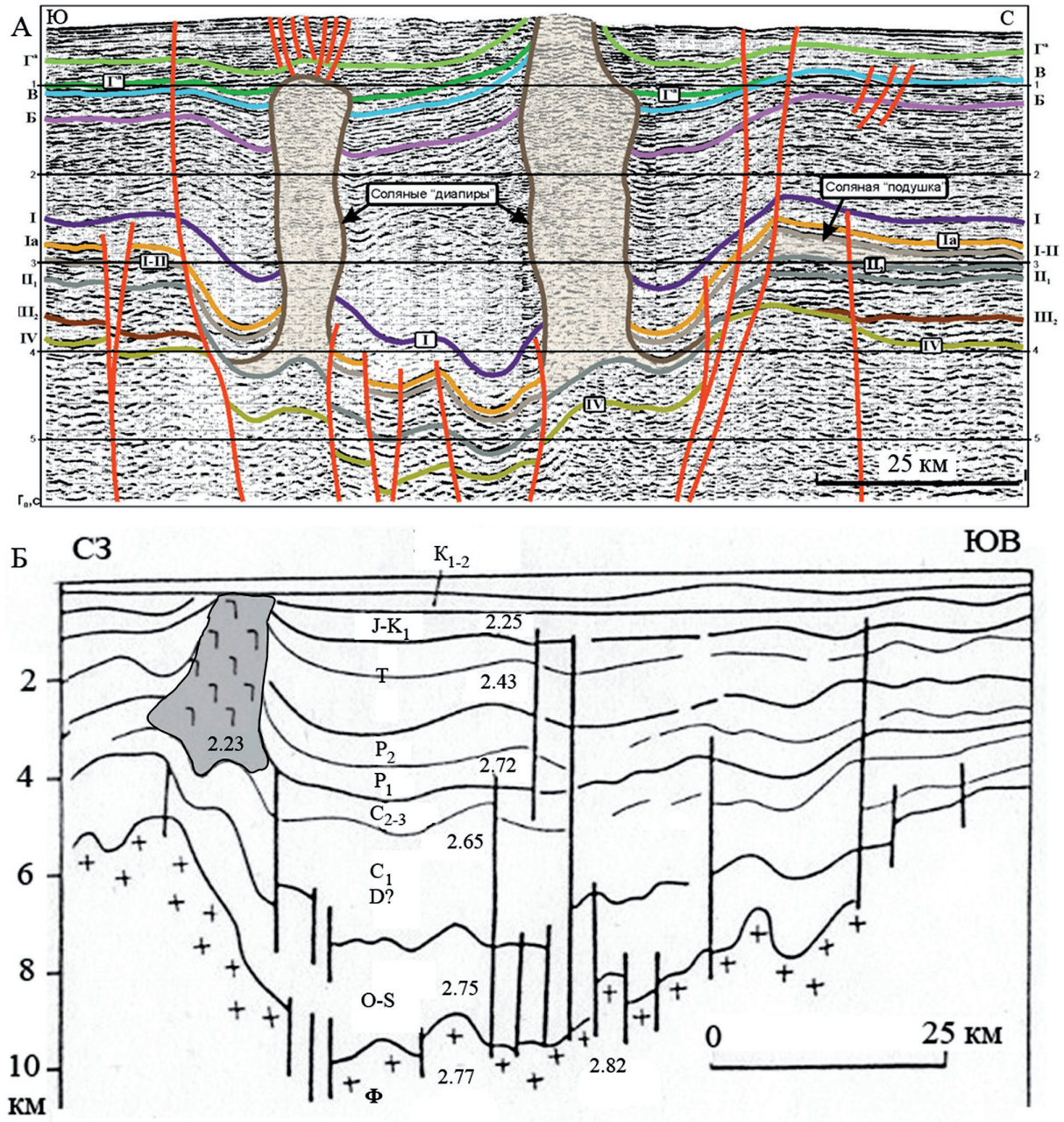

Рис.1. Эвапоритовый диапиризм в бассейнах запада Баренцевоморской континентальной окраины. А. Сейсмический разрез через Нордкапский прогиб $[8,10]$. Б. Сейсмогеологический разрез через бассейн Ольги $[1,11]$. 
волновой картиной. Нередко эвапоритовые тела акустически прозрачны. Имеются примеры, когда соляной диапир по сейсмическим материалам невозможно отличить от интрузии, либо от глиняного диапира (например, на Чукотском шельфе $[13,15])$. Иногда соляное тело характеризуется на сейсмических разрезах слоистостью.

В гравитационном поле диапировые структуры выражены локальными аномалиями отрицательных или пониженных на общем фоне значений. Расчетные плотности аномалеобразующих объектов составляют около 2.2 г $\mathrm{cm}^{3}$. Низкая расчетная плотность диапиров и отсутствие в их пределах магнитоактивных тел свидетельствуют об амагматической природе этих образований.

По формам залегания на сейсмических разрезах выделяются два основных типа соленосных структур: диапиры и подушки. Первые из них прорывают вышележащие отложения, которые образуют характерные асимметричные мульды с относительно пологими внешними и крутыми, прилегающими к диапирам, внутренними крыльями. Обычно диапиры сложены массивными солями (преимущественно галитом), а подушки - либо маломощными прослоями аналогичного состава, либо гипсо-ангидритовыми породами краевых фаций эвапоритовых бассейнов. Эвапориты карбона - ранней перми известны на Восточном Шпицбергене, о. Эдж и юге архипелага Новая Земля, а также в ордовике Северной Земли и девоне Нордвик-Хатангского района $[6,7,11,13]$. Таким образом, доказательство солянокупольной природы диапировых структур опирается на комплекс геофизических данных и подтверждается развитием соленосных отложений в разрезах сухопутного обрамления.
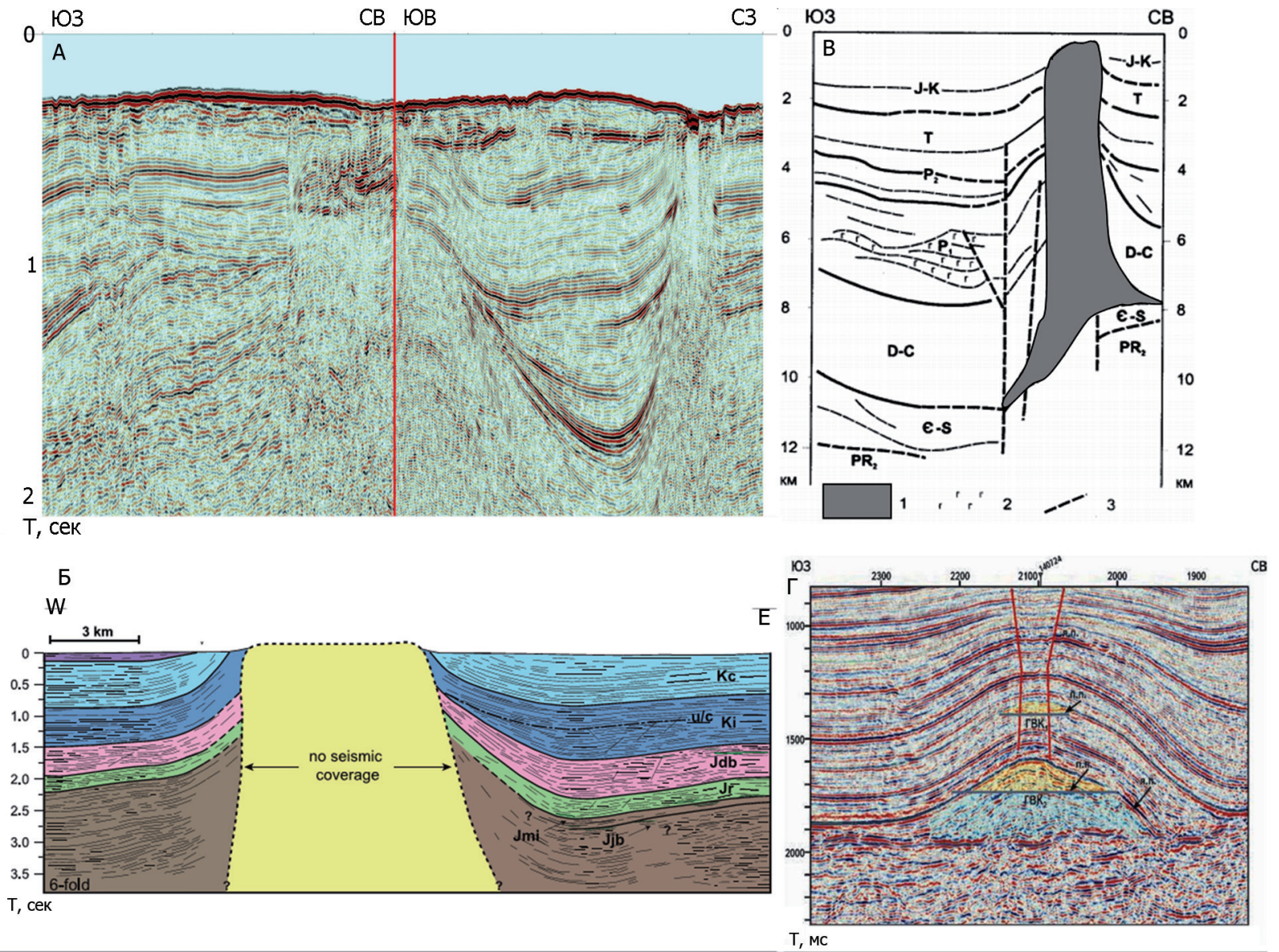

Рис. 2. Эвапоритовый диапиризм в бассейнах севера Карского шельфа, ю-з Лаптевоморского региона и Канадского Арктического архипелага. А. Волновая картина на сейсмическом разрезе МАГЭ иллюстрирующая проявление соляной тектоники в бассейне Воронина (Карская плита). Б. Соляная тектоника (Dumbells Dome) в Свердрупском бассейне, о-в Эллеф-Рингнес [12]. В. Сейсмогеологический разрез на с-в Енисей-Хатангского прогиба (Хатангский залив) [11]: 1 - соляной диапир, 2 - тела базальтоидов, 3 - разломы. Г. Сейсмический разрез иллюстрирующий строение отложений в прогибе Воронина с соляной подушкой (ордовик?) и прогнозируемой залежью УВ над ней $[2,5]$. 
На рис. 1 и 2 приведены фрагменты сейсмических и сейсмогеологических разрезов, иллюстрирующие проявления соляной тектоники в бассейнах западной части Баренцевоморского шельфа, северной части Карского шельфа, Хатангского залива и Канадского Арктического архипелага.

Возраст соленосных отложений в бассейнах Западно-Баренцевского шельфа (Медвежинский, Тромсё, Хаммерфест, Нордкапский, Варангерский, Ольги) определяется, исходя из сейсмостратиграфической интерпретации осадочных комплексов, как позднекаменноугольно-раннепермский и позднедевонский. Развитие последнего предполагается в пределах депрессионной части Нордкапского прогиба (рис. 1 А), где диапиры прорывают от 6 до 9 км верхнепалеозойских и мезозойских осадочных образований $[1,11]$.

Крупный соленосный бассейн (прогиб Ольги) выявлен к востоку от арх. Шпицберген в зоне сочленения Свальбардской антеклизы и Центрально-Баренцевских поднятий. Возраст соленосных отложений здесь датируется предположительно средне-поздне-каменноугольно-раннепермским временем в связи с тем, что в краевой части прогиба на о. Эдж скважиной вскрыты гипсо-ангидритовые отложения этого возраста. Общая мощность осадочного чехла в прогибе достигает 12-13 км. Диапировые структуры (рис. 1 Б), выявленные сейсмическими и гравимагнитными работами, тяготеют к бортовым, приразломным частям прогиба. По своим геофизическим параметрам они полностью отвечают критериям, отмеченным выше для солянокупольных структур. Все отмеченные бассейны имеют сходное строение, определяемое их рифтовой природой $[1,11,14]$.

На севере Карской плиты получил развитие бассейн Воронина (Краснофлотский). Строение его ранее было неизвестно, но по морфологии рельефа дна он сопоставлялся с прогибом Св. Анны. Сейсмические материалы показывают, что это достаточно глубокий прогиб, выполненный мощной толщей, скорей всего, преимущественно палеозойских образований. Здесь структуры связанные с соляными подушками и диапирами отмечаются на ряде разрезов (рис. 2 А). Они были ранее установлены работами СМНГ $[2,5]$ и подтверждены новейшими исследованиями МАГЭ. Представляется, что базовый уровень этих образований связан с отложениями ордовика-силура (?).

Енисей-Хатангский прогиб морской сейсморазведкой исследован на акватории моря Лаптевых в Хатангском заливе, где суммарная мощность кембрийско-меловых отложений превышает 10-12 км (рис. 2 В). По комплексу геолого-геофизических данных отмечается наличие соляных диапиров девонского возраста $[4,6,7]$, а также проявлений основного магматизма в виде дайковых и пластовых интрузий. По особенностям строения и характеру осадконакопления Енисей-Хатангский палеорифт имеет много общих черт с рассмотренными соленосными бассейнами западной части Баренцева моря - грабенами Нордкапским, Варангерским, Ольгинским, Медвежинским.

Еще одним бассейном Арктики, где известен эвапоритовый диапиризм, является Свердрупский, расположенный на островах Канадского Арктического архипелага. Его осадочное выполнение мощностью свыше 13 км представлено отложениями от карбона до эоцена включительно. Эвапоритовые образования представлены гипсами, ангидритами и галитом каменноугольного возраста. Многочисленные диапировые структуры изучены сейсморазведкой и бурением. Как и во многих других случаях, отмечается их асимметричная геометрия (рис. 2 Б). Диапиризм начался в среднем триасе и продолжался весь мезозой [12]. Рифтовый сценарий развития бассейна, очевидно, как и в бассейнах западной части Баренцева моря, сыграл определяющую роль в запуске диапиризма и формировании эвапоритовых куполов.

Среди причин, вызывающих рост соляных диапиров, называются такие факторы как литостатическое давление, горизонтальная компрессия, низкий удельный вес эвапоритов по сравнению с вмещающими породами, что способствовало их пластическому перетеканию в верхние горизонты осадочного чехла и др. Изучение геологической эволюции бассейнов позволяет говорить и о фазах рифтинга, выступающих в качестве триггера тектонической подвижности бассейнов континентальных окраин, особенно на этапах формирования спрединговых впадин Арктического региона.

Исследование геологического строения соленосных бассейнов имеет не только большое значение в связи с перспективами их нефтегазоносности (рис. 2 Г), но и с позиций определения широтного положения плит при палеотектонических реконструкциях (например, Карской плиты [9]). 


\section{Литература}

1. Боголепов А.К., Шипилов Э.В., Юнов А.Ю. Новые данные о соленосных бассейнах ЗападноАрктического шельфа Евразии // ДАН. Т. 317. N 4. 1991. С. 932-936.

2. Догунов К.А., Мартиросян В.Н., Васильева Е.А., Сапожников Б.Г. Структурно-тектонические особенности строения и перспективы нефтегазоносности северной части Баренцево-Карского региона // Геология нефти и газа. 2011. № 6. С. 70-83.

3. Иванова Н.М., Свистунов Ю.И., Шипилов Э.В. Структурные комплексы шельфа моря Лаптевых // IX Всесоюзная школа морской геологии: тезисы. М: ИО РАН. 1990. Т. 4. С. 60-61.

4. Конторович В.А. Тектоника и нефтегазоносность западной части Енисей-Хатангского регионального прогиба // Геология и геофизика. 2011. Т. 52 (8). С. 1027-1050.

5. Мартиросян В.Н., Васильева Е.А., Устрицкий В.И. и др. Север Карского моря - высокоперспективная на нефть область Арктического шельфа России // Геология нефти и газа. 2011. № 6. С. 59-69.

6. Полянский О.П., Ревердатто В.В., Ананьев В.А.Эволюция рифтогенного осадочного бассейна как индикатора геодинамической обстановки (на примере Енисей-Хатангского прогиба) // ДАН. 2000. Т. 370. № 1. C. 71-75.

7. Фрадкин Г.С. Галогенные формации и нефтегазоносность Сибирской платформы // Геология и геофизика. 2001. Т. 42. № 4. С. 605-616.

8. Шипилов Э.В., Шкарубо С.И. Современные проблемы геологии и тектоники осадочных бассейнов Евразиатско-Арктической континентальной окраины. Том. І. Литолого- и сейсмостратиграфические комплексы осадочных бассейнов Баренцево-Карского шельфа. Апатиты: Изд-во КНЦ РАН. 2010. 266 с.

9. Шипилов Э.В., Верниковский В.А. Строение области сочленения Свальбардской и Карской плит и геодинамические обстановки ее формирования // Геология и геофизика. 2010. Т. 51. № 1. С. 75-92.

10. Шкарубо С.И., Шипилов Э.В. Тектоника Западно-Арктической платформы // Разведка и охрана недр. 2007. № 9. C. 32-47.

11. Bogolepov A.K., Shipilov E.V., Yunov A.Yu. Saliferous Basins of the West-Arctic Eurasian Shelf // International Seminar on Tectonics of the Barents Sea-Kara Sea Region. Proceedings. Norway, Trondheim: NIIMorgeophysica, IKU sintef group, 1991. 4 p.

12. Boutelier J., Cruden A., Brent T., Stephenson R. Timing and mechanisms controlling evaporate diapirism on Ellef Ringnes Island, Canadian Arctic Archipelago // Basin Research. 2011. V. 23. P. 478-498.

13. Shipilov E.V., Bogolepov A.K., Thurston D.K. Riftogeneous Salt Bearing Basins of the Arctic Continental Margins // International Conference on Arctic Margins (ICAM - 1994): Abstracts. Magadan, 1994. P. 106.

14. Shipilov E.V., Senin B.V. Rift and Graben Systems of the Eurasian-Arctic Continental Margins // Proceedings of International Conference on Arctic Margins (ICAM -1992): Proceedings. Ancorage, Alaska, USA: US Dept. Interior Mineral Manag. Serv., 1992. P. 177-181.

15. Shipilov E.V., Senin B.V., Yunov A. Yu. Sedimentary cover and basement of Chukchi sea from seismic data // Geotectonics. 1989. T. 23. № 5. C. 456-463. 